\title{
Body Mass Index, Body Composition, and Leptin at Onset of Puberty in Male and Female Rats after Intrauterine Growth Retardation and after Early Postnatal Food Restriction
}

\author{
MIA J.T. ENGELBREGT, MIRJAM M. van WEISSENBRUCH, CORRIE POPP-SNIJDERS, \\ PAUL LIPS, AND HENRIETTE A. DELEMARRE-van de WAAL
}

Departments of Clinical Chemistry [M.J.T.E., C.P.-S.], Pediatrics [M.M.v.W., H.A.D.-v.d.W.], and Endocrinology [C.P.-S., P.L.], the Research Institute for Endocrinology, Reproduction and Metabolism, VU Medical Center, 1081 HV Amsterdam, The Netherlands

\begin{abstract}
In this study we examined the body composition at onset of puberty in intrauterine growth retarded (IUGR), postnatal food restricted (FR), and control male and female rats. IUGR was induced by ligation of the uterine artery on $\mathrm{d} 17$ of gestation and FR by litter enlargement to 20 pups per mother from d 2 after birth until weaning (d 24). We defined onset of puberty as balanopreputial separation in male rats and vaginal opening in female rats. We calculated body mass index, measured body composition with dual-energy x-ray absorptiometry, and measured leptin concentrations in serum. It was reported previously that early malnutrition, either during late gestation or immediately postnatally, results in a delayed onset of puberty in IUGR and FR male rats and in IUGR female rats, but not in FR female rats. In IUGR male rats at balanopreputial separation and in IUGR female rats at vaginal opening no differences were found in body mass index, body composition, and leptin levels compared with controls. FR male rats had a significantly lower
\end{abstract}

\section{ABSTRACT}

percentage of fat and serum leptin concentrations at balanopreputial separation. FR female rats had a significantly lower body mass index, percentage of fat, and serum leptin concentrations at vaginal opening. We conclude that the onset of puberty in the rat is not dependent on a certain percentage of body fat or a certain threshold of circulating levels of leptin and that food deprivation during different "critical" time periods around birth results in different effects in later life. (Pediatr Res 50: 474-478, 2001)
Abbreviations
IUGR, intrauterine growth retardation
FR, food restriction
VO, vaginal opening
BPS, balanopreputial separation
BMI, body mass index
DXA, dual-energy x-ray absorptiometry

With limited food supply, animals are forced to set priorities. Shutting off reproductive function during times of food scarcity may be desirable for the survival of a species (1-3). In 1996 Wade et al. (2) noticed that nutritional infertility is particularly observed in females, which is not surprising. A complete reproductive cycle of ovulation, conception, pregnancy, and lactation is one of the most energy-consuming activities that a female mammal can undertake, particularly in species that bear multiple young. In female rats food deprivation simply disrupts the sequential secretion of estradiol and progesterone necessary to induce estrous behavior (2), and reproduction can be resumed when energetic conditions improve. In male rats acute underfeeding stops reproduction by suppressing androgen pro-

Received October 4, 2000; accepted February 15, 2001

Correspondence and reprint requests: M.J.T. Engelbregt, Laboratory of Endocrinology, brug 214, VU Medical Center, PO Box 7057, 1007 MB Amsterdam, The Netherlands; e-mail: m.engelbregt@azvu.nl duction and sexual behavior, rather than by suppressing spermatogenesis, as the former could be restored faster than the latter after food supplies are resumed (3). In the studies mentioned above the circumstances of acute malnutrition are discussed. In our study we investigated the consequences of perinatal food deprivation on the process of sexual maturation with respect to body composition and leptin in later life.

In an earlier study we showed that prenatal or postnatal malnutrition affects the onset of puberty in both male and female rats. We are aware that the pubertal development starts soon after weaning, but BPS in the male rat and VO in the female rat are the first visual signs during this development. Therefore we used these external signs as measures of onset of puberty, which are commonly used in literature. The male rats in both malnourished models had a significantly delayed BPS, and the female IUGR rats had a significantly delayed VO, although the female FR rats had $\mathrm{VO}$ at a similar age as 
controls. Weight at onset of puberty did not seem to play a critical role in the process of sexual maturation (4). Frisch et al. (5) and Frisch (6) hypothesized that, more than weight, an appropriate body composition or a certain percentage of fat is needed to start puberty in rats. It might be sensible that a low percentage of fat will delay an important event such as puberty and the start of the fertile period until the body is ready for it. The metabolic pathway to link body fat stores with the neuroendocrine reproductive system was unclear until the discovery of leptin, which may represent the long-sought metabolic signal that triggers puberty (7-10). In view of that point, body composition may still be an important determinant for reproductive ability. In this study we examined at onset of puberty the body composition in male and female rats, which were undernourished by IUGR or early postnatal food deprivation, to investigate the influence of body fat mass on pubertal development. We used BMI as a measure of the body fat mass. DXA, which has emerged as an excellent noninvasive technique for measuring bone, fat, and lean tissue in the rat (11), was used to measure fat and lean tissue mass, and leptin analyses were performed in serum.

\section{METHODS}

IUGR rats. IUGR was induced by ligation of the uterine artery on 17 of gestation according to the method of Wigglesworth (12) in timed pregnant Wistar rats, obtained from Harlan CPB (Horst, The Netherlands). The animals were housed under a constant light-dark cycle with lights on from $0600 \mathrm{~h}-1800 \mathrm{~h}$ and controlled temperature $\left(21-23^{\circ} \mathrm{C}\right)$. The pups were born spontaneously on d 21-22 and defined as IUGR if their weight on $\mathrm{d} 2$ after birth was $<5.3 \mathrm{~g}$, corresponding with $-2 \mathrm{SD}$ of the mean of control pups, born from sham-operated dams (mean weight, $6.3 \mathrm{~g}$ ).

FR rats. Postnatal FR was achieved by litter enlargement to 20 pups per mother from $\mathrm{d} 2$ after birth until weaning, which is in our laboratory $\mathrm{d} 24$, i.e. a period of $22 \mathrm{~d}$.

Onset of puberty. After weaning at d 24, males and females were separated. Respectively two males and three females were kept per cage with ad libitum food and water. From d 40 onward, the males were inspected daily for BPS to assess onset of puberty, defined as age in days at which BPS occurred. From d 30 onward, the females were inspected daily for VO to assess onset of puberty, defined as age in days at which VO occurred. At BPS and VO, body weight, total length, and tail length (tip of tail to anus) were recorded, body length was calculated (total length minus tail length), and the rats were killed with an i.p. pentobarbital sodium injection at $1000 \mathrm{~h}$. Blood, collected via cardiac puncture, was centrifuged, and serum was stored at $-20^{\circ} \mathrm{C}$ until assayed for leptin.

Measurements. BMI was calculated by dividing body weight (grams) by body length squared (square centimeters). Body composition was measured with DXA (QDR 2000, Hologic, Waltham, MA, U.S.A.), using the small animal software package. This software provides data on total body fat mass, total body lean soft tissue mass, and total body bone mineral content. In advance, the application of the software in very young animals had been validated (13).
Hormone determinations. Serum leptin concentrations were measured by an RIA special for rats (Mediagnost, Tuebingen, Germany). Values are reported in nanograms per milliliter of serum. All the samples were analyzed within one run. The intraassay coefficient of variation was $5 \%$ for levels between 0.2 and $0.5 \mathrm{ng} / \mathrm{mL}$.

For all experiments, approval was obtained from the Animal Welfare Committee (DEC) of the Vrije Universiteit of Amsterdam.

Statistical analysis. Data are expressed as mean \pm SD. Statistical analyses were performed using one-way ANOVA, followed by Dunnett's test for multiple comparison of the two treatment groups with the control. Statistical significance was defined as $p<0.05$.

\section{RESULTS}

Male IUGR and FR rats at onset of puberty. At onset of puberty body weight did not differ between IUGR rats $(n=10$, $177.5 \pm 14.3 \mathrm{~g}$, mean $\pm \mathrm{SD})$ and controls $(n=12,187.6 \pm$ $10.3 \mathrm{~g})$, but body weight in FR rats $(n=16,176.4 \pm 11.6 \mathrm{~g})$ was significantly lower compared with controls $(p<0.05)$.

Figure $1 A$ shows BMI in IUGR, FR, and control male rats. BMI was not different among the two growth-retarded groups and control rats: IUGR, $0.5270 \pm 0.038 \mathrm{~g} / \mathrm{cm}^{2} ; \mathrm{FR}, 0.5386 \pm$ $0.025 \mathrm{~g} / \mathrm{cm}^{2}$; and controls, $0.5341 \pm 0.035 \mathrm{~g} / \mathrm{cm}^{2}$. The absolute fat mass did not differ between IUGR rats $(20.62 \pm 3.9 \mathrm{~g})$ and controls $(22.77 \pm 3.9 \mathrm{~g})$, but was significantly lower in FR rats $(18.62 \pm 3.4 \mathrm{~g})$ compared with controls $(p<0.05$, Fig. $2 A)$. No difference was seen in percentage of fat between IUGR rats $(11.55 \pm 1.6 \%)$ and controls $(12.15 \pm 1.9 \%)$, but the percentage of fat was significantly lower in FR rats $(10.54 \pm 1.7 \%)$ compared with controls $(p<0.05$, Fig. $2 B$ ). The percentage of lean mass (Fig. 2C) did not differ between the IUGR rats $(78.92 \pm 1.6 \%)$ and controls $(77.61 \pm 2.0 \%)$, but was significantly higher in FR rats $(80.25 \pm 1.6 \%)$ compared with controls $(p<0.01)$. Serum leptin concentrations (Fig. 1B) did not differ between IUGR rats $(n=6,3.0 \pm 1.2 \mathrm{ng} / \mathrm{mL})$ and controls $(n=8,3.0 \pm 1.0 \mathrm{ng} / \mathrm{mL})$, but leptin concentrations were significantly decreased in the FR rats $(n=13,2.1 \pm 0.7$ $\mathrm{ng} / \mathrm{mL})$ compared with controls $(p<0.05)$. Leptin levels expressed as concentration per gram fat mass (Fig. 1C) did not differ between IUGR rats $(0.14 \pm 0.04 \mathrm{ng} / \mathrm{g}$ fat mass $)$ and controls $(0.13 \pm 0.03 \mathrm{ng} / \mathrm{g}$ fat mass $)$ and between FR rats $(0.12 \pm 0.03 \mathrm{ng} / \mathrm{g}$ fat mass) and controls.

Female IUGR and FR rats at onset of puberty. At onset of puberty body weight was significantly lower in IUGR rats $(n=$ $18,108.5 \pm 12.8 \mathrm{~g}, p<0.01)$ and in FR rats $(n=9,83.7 \pm$ $8.1 \mathrm{~g}, p<0.01)$ compared with controls $(n=13,123.6 \pm$ $11.3 \mathrm{~g})$.

Figure $1 A$ shows $\mathrm{BMI}$ in the female rats. No difference was seen in BMI between IUGR rats $\left(0.4616 \pm 0.018 \mathrm{~g} / \mathrm{cm}^{2}\right)$ and controls $\left(0.4774 \pm 0.027 \mathrm{~g} / \mathrm{cm}^{2}\right)$, but BMI was significantly decreased in FR rats $\left(0.4038 \pm 0.025 \mathrm{~g} / \mathrm{cm}^{2}\right)$ compared with controls $(p<0.01)$. The total fat mass (Fig. $2 A)$ was significantly lower in IUGR rats $(13.07 \pm 2.5 \mathrm{~g})$ compared with controls $(15.33 \pm 2.4, p<0.05)$ and in FR rats $(8.133 \pm 1.5$ g) compared with controls $(p<0.01)$. The percentage of fat 
(Fig. $2 B)$ was not different between IUGR rats $(12.01 \pm 1.4 \%)$ and controls $(12.39 \pm 1.6 \%)$, but was significantly lower in FR rats $(9.67 \pm 1.2 \%)$ compared with controls $(p<0.01)$. The percentage of lean mass (Fig. 2C) was similar in IUGR rats $(77.56 \pm 1.5 \%)$ and controls $(76.99 \pm 1.7 \%)$, but was significantly higher in FR rats $(78.84 \pm 1.0 \%)$ compared with controls $(p<0.05)$. Serum leptin concentrations (Fig. $1 B)$ did not differ between IUGR rats $(n=15,2.2 \pm 1.2 \mathrm{ng} / \mathrm{mL})$ and controls $(n=10,2.5 \pm 1.0 \mathrm{ng} / \mathrm{mL})$, but were significantly lower in the FR rats $(n=9,1.4 \pm 0.4 \mathrm{ng} / \mathrm{mL})$ compared with controls $(p<0.05)$. Leptin levels expressed as concentration per gram fat mass (Fig. 1C) did not differ between IUGR rats $(0.17 \pm 0.06 \mathrm{ng} / \mathrm{g}$ fat mass $)$ and control rats $(0.14 \pm 0.06 \mathrm{ng} / \mathrm{g}$ fat mass) and between FR rats $(0.17 \pm 0.03 \mathrm{ng} / \mathrm{g}$ fat mass $)$ and controls.
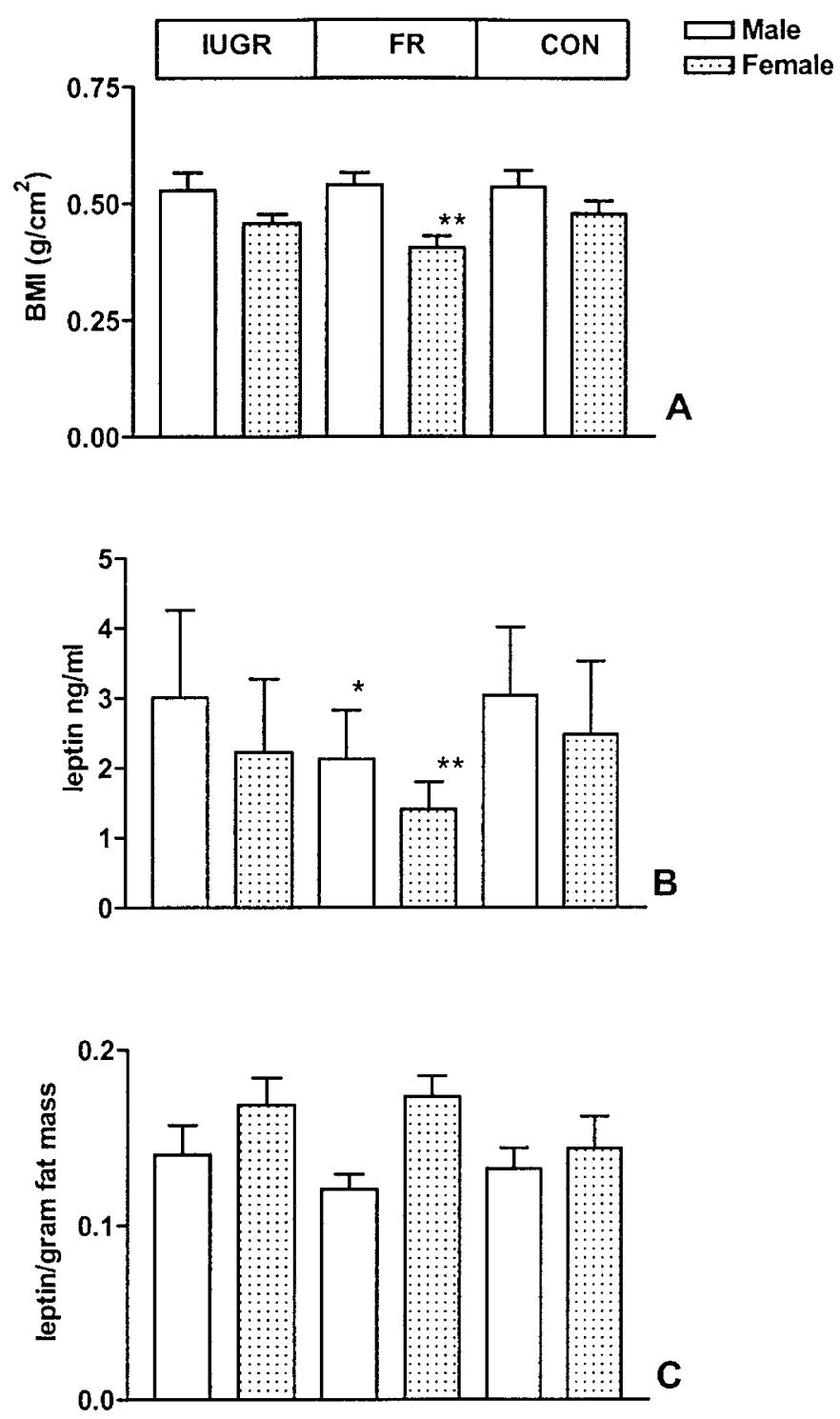

Figure 1. BMI $(A)$ and leptin $(B, C)$ in male and female rats at onset of puberty. Values are expressed as mean $\pm \mathrm{SD} .{ }^{*} p<0.05$, FR rats $v s$ control $(\mathrm{CON})$ rats; $* * p<0.01$, FR rats $v s \mathrm{CON}$ rats.
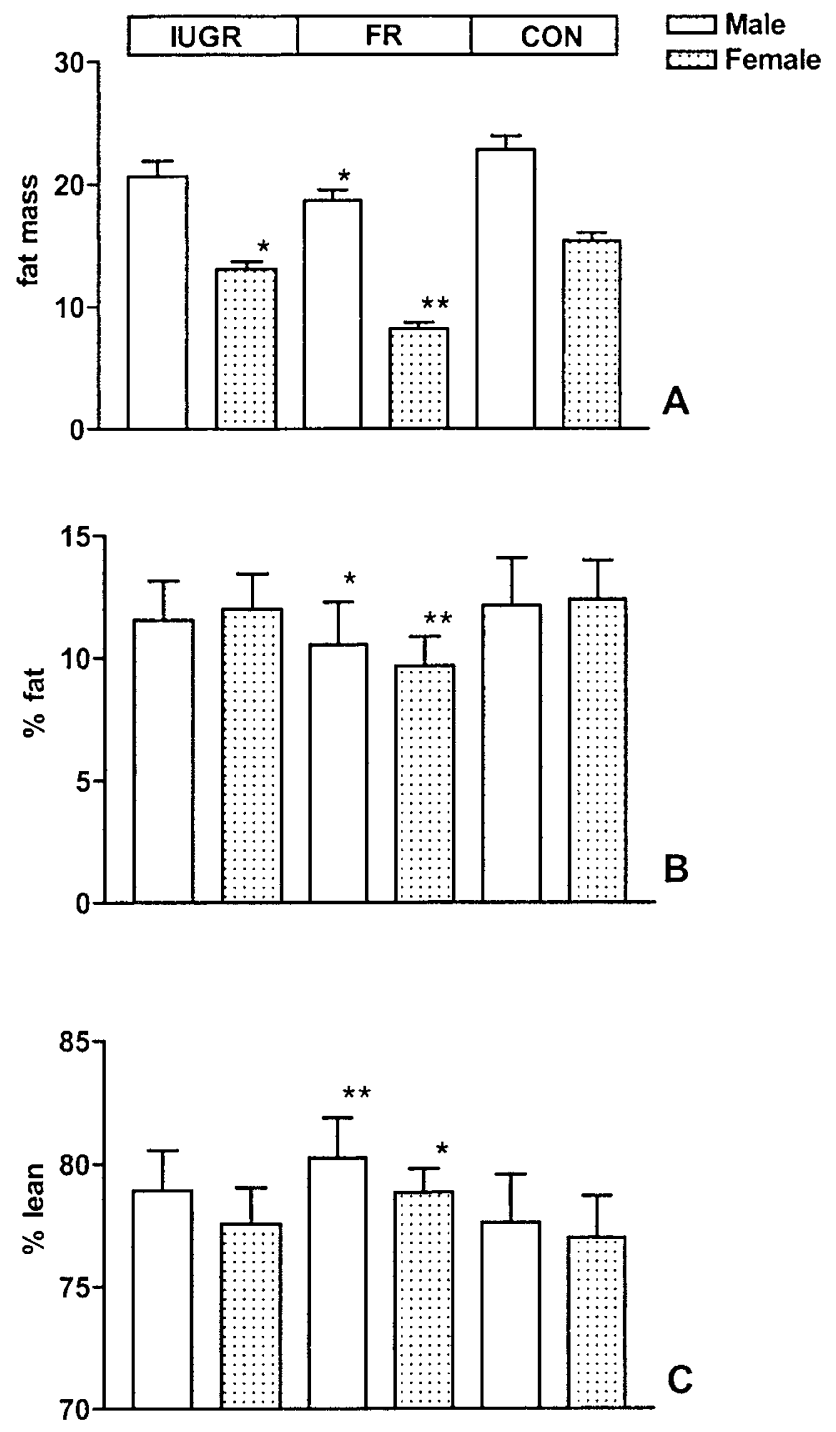

Figure 2. Total fat mass $(A), \%$ fat $(B)$, and $\%$ lean $(C)$ in male and female rats at onset of puberty. Values are expressed as mean $\pm \mathrm{SD} .{ }^{*} p<0.05$, IUGR rats and FR rats $v s$ control $(\mathrm{CON})$ rats; ${ }^{* *} p<0.01$, FR rats $v s$ CON rats.

\section{DISCUSSION}

In the present study we focused on the body composition in growth-retarded rats at onset of puberty. In general BMI is an easily obtainable, widely accepted measurement in human studies, showing correlations with percentage body fat (1416), absolute fat mass (17), lean body mass (15), and serum leptin $(14,16,17)$. In rats only a correlation between BMI and leptin was reported (14). In this study we used DXA, which could give us not only more insight into body composition at onset of puberty in these growth-retarded rats, but also an answer to the question of whether a certain percentage of fat is needed to start puberty.

IUGR male and female rats. At onset of puberty we did not find differences in BMI and body composition in IUGR male and female rats compared with controls. We therefore believe that in IUGR rats the normal nutritional circumstances and metabolic conditions postnatally lead to normal body composition at onset of puberty. The onset of puberty was delayed in both male and female IUGR rats compared with controls (4), 
and in female IUGR rats body weight and absolute amounts of fat tissue were significantly decreased compared with controls. However, the percentage of fat in the IUGR female rats did not differ from the controls. These results may confirm the hypothesis of Frisch et al. (5) and Frisch (6) that a certain percentage of fat is needed to start puberty, although no other data exist that support a causal relationship between body fat content and fertility (1). In contrast with Frisch, Glass et al. (18) have shown that accumulation of body fat merely accompanies sexual maturation in rats and that no critical level in percentage of body fat is needed to trigger puberty in the rat.

The circulating levels of the hormone leptin, which is secreted by the adipose tissue and especially acts in the brain, might represent the relationship between fat stores and the endocrine reproductive processes in the brain. In the IUGR male and female rats serum leptin concentrations did not differ from the controls. Leptin levels tended to be higher in males than in females, which is in agreement with other studies in rats (19). Furthermore, in our study, a higher fat mass was observed in male rats, which reflects the higher leptin levels. We tried to find a correlation between BMI and body composition in the groups on the one hand and between leptin and body composition on the other hand. However, owing to the low number of animals in each group, it is difficult to draw a meaningful conclusion about this.

Although in our study we did not find differences in serum leptin levels between IUGR rats and controls, reproductive failure can still be observed in fasted animals despite adequate leptin levels (20-22). In addition, leptin treatment cannot overcome the suppression of sexual behavior in food-deprived female hamsters (22), and in growth-retarded female rats mating behavior was often absent even after the start of normal cycles (23). At VO we did not observe any sign of first estrous and ovulation in female IUGR rats, in contrast to control rats in which VO was accompanied by estrous and ovulation, shown by vaginal smears and morphologically by corpora lutea in the ovary (24). These results suggest that sexual maturation has not yet been completed.

FR male and female rats. Although weight was significantly lower in FR male rats compared with controls at onset of puberty, BMI was not different. However, measurements by DXA revealed a significantly lower total fat mass and percentage of fat tissue and a significantly higher percentage of lean tissue. In addition, leptin concentrations were significantly lower compared with controls. This indicates that at least at onset of puberty, BMI is not a good index for body fat mass in the male rat. A possible explanation could be that weight in the FR rats increases relatively more than length during sexual development after normal food supply has started. The low leptin levels and decreased measurements with respect to fat mass and percentage fat obtained by DXA suggest inadequate metabolic conditions in the FR rats, which might have consequences for sexual maturation. However, calculating leptin as concentration per gram fat mass revealed no differences between FR male rats and controls. This suggests that a normal amount of leptin is produced by a low number of adipocytes present in the FR rats. In the FR female rats, BMI as well as body weight was significantly decreased compared with con- trols. Total fat mass, percentage of fat tissue, and leptin concentrations were significantly decreased compared with control rats, whereas the percentage of lean tissue was significantly increased. These findings suggest that in the FR female rats at onset of puberty, the energy reserves are not adequate to meet the demands for mating and pregnancy. Just as in the FR male rat, calculating leptin as concentration per gram fat mass neutralized the significant difference between the FR female rats and the controls. This suggests that also in the female rat serum leptin concentrations are determined by the amount of fat mass. In addition, similar to the IUGR rats we did not observe estrous and ovulation at $\mathrm{VO}$ in the FR rats.

In summary, critical time periods exist around birth in the rat, in which food deprivation results in different effects later in life. In IUGR male as well as in IUGR female rats, the onset of puberty is delayed, but IUGR does not affect the physiologic relationship between body fat stores and leptin secretion. Early postnatal FR results in a delayed BPS whereas VO occurs on time. FR also leads to an impaired development of body composition and low leptin concentrations at onset of puberty, which may result in an impaired sexual maturation in male and female rats. We therefore conclude that the onset of puberty in the rat is not dependent on a certain percentage of body fat or a certain threshold of circulating levels of leptin.

Acknowledgment. The authors thank Anneke Frans from the laboratory of endocrinology for performing the leptin analyses.

\section{REFERENCES}

1. Wade GN, Schneider JE 1992 Metabolic fuels and reproduction in female mammals. Neurosci Biobehav Rev 16:235-272

2. Wade GN, Schneider JE, Li HY 1996 Control of fertility by metabolic cues. Am J Physiol 270:E1-E19

3. Glass AR, Herbert DC, Anderson J 1986 Fertility onset, spermatogenesis and pubertal development in male rats: effect of graded underfeeding. Pediatr Res 20:1161-1167

4. Engelbregt MJT, Houdijk ECAM, Popp-Snijders C, Delemarre-van de Waal HA 2000 The effects of intra-uterine growth retardation and postnatal undernutrition on onset of puberty in male and female rats. Pediatr Res 48:803-807

5. Frisch RE, Hegsted DM, Yoshinaga K 1977 Carcass components at first estrus of rats on high-fat and low-fat diets: body water, protein, and fat. Proc Natl Acad Sci USA $74: 379-383$

6. Frisch RE 1980 Pubertal adipose tissue: is it necessary for normal sexual maturation? Evidence from the rat and human female. Fed Proc 39:2395-2400

7. Bronson FH, Manning JM 1991 The energetic regulation of ovulation: a realistic role for body fat. Biol Reprod 44:945-950

8. Aubert ML, Pierroz DD, Gruaz NM, d'Allèves V, Vuagnat BAM, Pralong FP, Blum WF, Sizonenko PC 1998 Metabolic control of sexual function and growth: role of neuropeptide Y and leptin. Mol Cell Endocrinol 140:107-113

9. Nazian SJ, Cameron DF 1999 Temporal relation between leptin and various indices of sexual maturation in the male rat. J Androl 20:487-491

10. Campfield LA, Smith FJ, Burn P 1996 The OB protein (leptin) pathway-a link between adipose tissue mass and central neural networks. Horm Metab Res 28:619632

11. Grier SJ, Turner AS, Alvis MR 1996 The use of dual-energy x-ray absorptiometry in animals. Invest Radiol 31:50-62

12. Wigglesworth JS 1964 Experimental growth retardation in the foetal rat. J Pathol Bacteriol 88:1-13

13. Engelbregt MJT, Tromp AM, van Lingen A, Lips P, Popp-Snijders C 1999 Validation of whole body DXA in young and adult rats. Horm Res 51 (suppl 2): P428

14. Maffei M, Halaas J, Ravussin E, Pratley RE, Lee GH, Zhang Y, Fei H, Kim S, Lallone R, Ranganathan S, Kern PA, Friedman JM 1995 Leptin levels in human and rodent: measurement of plasma leptin and $o b$ RNA in obese and weight-reduced subjects. Nat Med 1:1155-1161

15. Twisk JW, Kemper HC, van Mechelen W, Post GB, van Lenthe FJ 1998 Body fatness: 
longitudinal relationship of body mass index and the sum of skinfolds with other risk factors for coronary heart disease. Int J Obes Relat Metab Disord 22:915-922

16. Blum WF, Englaro P, Hanitsch S, Juul A, Hertel NT, Müller J, Skakkebaek NE, Heiman ML, Birkett M, Attanasio AM, Kiess W, Rascher W 1997 Plasma leptin levels in healthy children and adolescents: dependence on body mass index, body fat mass, gender, pubertal stage and testosterone. J Clin Endocrinol Metab 82:2904-2910

17. Horlick MB, Rosenbaum M, Nicolson M, Levine LS, Fedun B, Wang J, Pierson Jr RN, Leibel RL 2000 Effect of puberty on the relationship between circulating leptin and body composition. J Clin Endocrinol Metab 85:2509-2518

18. Glass AR, Dahms WT, Swerdloff RS 1979 Body fat at puberty in rats: alteration by changes in diet. Pediatr Res 13:7-9

19. Landt M, Gingerich RL, Havel PJ, Mueller WM, Schoner B, Hale JE, Heiman ML 1998 Radioimmunoassay of rat leptin: sexual dimorphism reversed from humans. Clin Chem 44:565-570
20. Cheung CC, Thornton JE, Kuijper JL, Weigle DS, Clifton DK, Steiner RA 1997 Leptin is a metabolic gate for the onset of puberty in the female rat. Endocrinology 138:855-858

21. Cunningham MJ, Clifton DK, Steiner RA 1999 Leptin's actions on the reproductive axis: perspectives and mechanisms. Biol Reprod 60:216-222

22. Wade GN, Lempicki RL, Panicker AK, Frisbee RM, Blaustein JD 1997 Leptin facilitates and inhibits sexual behavior in female hamsters. Am J Physiol 272:R1354R1358

23. Kennedy GC, Mitra J 1963 Body weight and food intake as initiating factors for puberty in the rat. J Physiol (Lond) 166:408-418

24. Engelbregt MJT, van Weissenbruch MM, Popp-Snijders C, Delemarrevan de Waal HA 2000 Impaired ovarian development in intra-uterine growth retarded rats at the onset of puberty. Horm Res 53(suppl 2):OR544 